\title{
Study of vitamin d levels in patients with type 2 diabetes mellitus
}

\author{
Srujan JV. ${ }^{1 *}$, Prakash Rao . $^{2}$
}

DOI: https://doi.org/10.17511/ijmrr.2021.i01.02

1* J.V. Srujan, Assistant Professor, Department of General Medicine, NRI Institute of Medical Sciences, Sangivalasa, Andhra Pradesh, India.

2 Surya Prakash Rao, Professor, Department of Medicine, NRI Institute of Medical Sciences, Sangivalasa, Andhra Pradesh, India.

Introduction: Diabetes is defined as a disturbance in intermediary metabolism manifesting as chronic sustained hyperglycemia, primarily due to either an absolute or a relative lack of insulin. Many epidemiological studies have demonstrated an inverse relationship between vitamin $D$ levels and diabetes mellitus. However, there is a paucity of literature regarding the levels of vitamin $D$ in type 2 diabetes, which is common in our community. This study was taken up to shed more light on this issue. Material and methods: This was a cross-sectional study conducted at NRI Institute of Medical Sciences, Sangivalasa, Visakhapatnam district. Cases of Type 2 Diabetes Mellitus attending to the outpatient department, diagnosed as per the ADA criteria of 2011, between the ages of 31 and 75 years constituted the material for the present study. Results and conclusion: Vitamin $D$ levels were found to be significantly lower in the study group $(19.91 \pm 7.0 \mathrm{ng} / \mathrm{ml})$ as compared to the control group $(32.22 \pm 4.0 \mathrm{ng} / \mathrm{ml})$.

Keywords: Diabetes mellitus, Vitamin D, Vitamin D level

Corresponding Author

J.V. Srujan, Assistant Professor, Department of General Medicine, NRI Institute of Medical Sciences, Sangivalasa, Andhra Pradesh, India. Email: srujanmims@gmail.com

\section{How to Cite this Article}

Srujan JV, Rao SP. Study of vitamin d levels in patients with type 2 diabetes mellitus. Int J Med Res Rev. 2021;9(1):13-20.

Available From

https://ijmrr.medresearch.in/index.php/ijmrr/article/ view/1243
To Browse

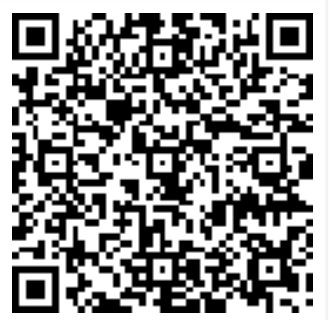

Manuscript Received 2021-01-07

Conflict of Interest No
Review Round 1 2021-01-15

Funding
Review Round 2

2021-01-25

Ethical Approval Yes
Review Round 3

Plagiarism X-checker $7 \%$
Accepted 2020-01-30

Note 


\section{Introduction}

Diabetes is defined as a disturbance in intermediary metabolism manifesting as chronic sustained hyperglycemia, primarily due to either an absolute or a relative lack of insulin. Diabetes is a polygenic and multifactorial disease involving many pathways and mechanisms. There were an estimated 20 - 40 million people with diabetes in India in 2007.

It is projected that by the year 2025, there would around 300 million diabetics worldwide and India would emerge as the diabetic capital of the world with around 60 million diabetics [1]. In recent years emphasis has been given to the role of vitamin $D$ in areas beyond those traditionally known. Many epidemiological studies have demonstrated an inverse relationship between vitamin $\mathrm{D}$ levels and diabetes mellitus $[2,3]$.

Studies in India have demonstrated that the level of vitamin $D$ in the population is low and there is a high prevalence of chronic diseases like diabetes, hypertension, and cardiovascular disease. However, there is a paucity of literature regarding the levels of vitamin $D$ in type 2 diabetes, which is common in our community.

Because of the above facts, the present study has been undertaken to determine the occurrence of hypovitaminosis D in Type 2 Diabetes Mellitus and to compare these with that of non-diabetic controls.

The present study was undertaken:

01. To study plasma 25-Hydroxycholecalciferol (Vitamin D3) levels in patients of type 2 diabetes and to compare it with age and sexmatched control subjects.

02. To study the correlation if any, with severity and duration of disease with vitamin D3 levels.

\section{Material and Methods}

Setting: This study was conducted in the outpatient department of the Department of General Medicine of NRI Institute of Medical Sciences, Sangivalasa, Visakhapatnam, Andhra Pradesh, India

Duration and type of study: This was a crosssectional study, conducted over 2 months from September to October 2020.

Sampling Methods: People who met the inclusion and exclusion criteria were selected by simple random sampling
Inclusion criteria: Type 2 diabetic patients between age 31 - 75 years

\section{Exclusion criteria:}

01 . Age less than 30 years or more 75 years

02. Patients with type 1 diabetes

03. Patients with co-morbid conditions likely to influence Vitamin D levels in the blood like Chronic kidney disease, Chronic Liver disease, Cardiovascular disease, Cerebrovascular disease, Patients taking drugs that affect vitamin D metabolism e.g. anti-epileptic drugs, steroids, rifampicin, ART, antacids, orlistat, statins.

04. Patients taking vitamin D or calcium supplements

05. Patients with hypertension

06. Patients not giving consent for the study

\section{Data collection procedure:}

Complete clinical history was taken and physical examination was performed on 60 patients.

All patients underwent the following investigations:

01. Fasting blood glucose level

02. A postprandial blood glucose level

03. Serum calcium

04. Serum creatinine

05. Urine for micro-albumin

06. Plasma 25-hydroxy Cholecalciferol

07. Serum Parathyroid hormone

08. Liver function tests including serum albumin

09. HbA1C

Ethical consideration: This study was conducted after obtaining due permission from the institutional ethics committee.

Statistical Analysis: Data was collected and tabulated using Microsoft Excel software. Descriptive and inferential statistical analysis was carried out. Results of continuous measurements are presented as Mean \pm SD (Min-Max) and results on categorical measurements are presented in Number (\%). Significance is assessed at a $5 \%$ level of significance. The relationship between two variables of the sample was analyzed using the Chi-Square test. Statistical analysis was done using the MedCalc statistical software. 


\section{Results}

This was a cross-sectional study performed on 30 diabetic and non-diabetic controls. The Biochemistry Department of NRI Institute of Medical Sciences performed the vitamin $D$ levels by using the Chemiluminescence Immunoassay (CLIA) method.

The findings are tabulated as follows.

Table-1: Age-sex distribution of the cases and controls.

$x$ Control

\begin{tabular}{|l|l|l|l|l|}
\hline & \multicolumn{2}{|c|}{ Case } & \multicolumn{2}{c|}{} \\
\hline Age (Years) & Male & Female & Male & Female \\
\hline $31-40$ & 3 & 2 & 7 & 5 \\
\hline $41-50$ & 8 & 4 & 5 & 2 \\
\hline $51-60$ & 9 & 2 & 11 & 0 \\
\hline $61-70$ & 2 & 0 & 0 & 0 \\
\hline $71-75$ & 0 & 0 & 0 & 0 \\
\hline Subtotal & 22 & 8 & 23 & 7 \\
\hline Total & 30 & & 30 & \\
\hline
\end{tabular}

The baseline characteristics of the study and control population were similar. Out 30 of cases, 22 (73.4\%) were males and $8(26.6 \%)$ were females and out of 30 controls 23 (76.7\%) were males and $7(23.3 \%)$ were females (Table 1 ). The majority of the cases were from the 41 to 50 years age group followed by the 51 to 60 years age group and in the control group majority of the population were from the 31 to 40 years age group followed by the 51 to 60 years age group. There were 2 patients above 60 in the case group.

Table-2: Distribution according to the duration of diabetes.

\begin{tabular}{|l|l|}
\hline \multicolumn{1}{|c|}{ Duration of Diabetes } & \multicolumn{1}{c|}{ Number of cases (\%) } \\
\hline One Year or Less & $11(33.6)$ \\
\hline $2-5$ Years & $14(46.6)$ \\
\hline $5-10$ Years & $4(13.3)$ \\
\hline More Than 10 Years & $1(3.3)$ \\
\hline Total & 30 \\
\hline
\end{tabular}

Among the diabetics 11 (33.6\%) of them were diagnosed to be diabetic less than or equal to a year from the time of the study, 14 (46.6\%) were diagnosed between 2 to 5 years, 4 (13.3\%) of them were diagnosed between 5 to 10 years and only 1 (3.3\%) had long-standing diabetes of greater than 10 years (Table 2 ).

\begin{tabular}{|l|l|}
\hline \multicolumn{1}{|c|}{ Type of drug } & \multicolumn{1}{c|}{ Patients (\%) } \\
\hline OHA & $19(63.3)$ \\
\hline Insulin only & $7(23.3)$ \\
\hline Both & $4(13.3)$ \\
\hline
\end{tabular}

Total

Table-3: Type of drugs used by the study population.

OHA - Oral Hypoglycemic Agents

BOTH - Using a combination of Insulin and Metformin

All of them were on anti-diabetic medications with $19(63.3 \%)$ of them on OHA's, $7(23.3 \%)$ patients on insulin only, and $4(13.3 \%)$ patients were on a combination of both insulin and metformin. (Table 3).

Table-4: Compliance with Anti-Diabetic medications.

\begin{tabular}{|l|l|}
\hline \multicolumn{1}{|c|}{ Compliance } & \multicolumn{1}{c|}{ Cases (\%) } \\
\hline Good & $16(53.3)$ \\
\hline Average & $10(33.3)$ \\
\hline Poor & $4(14.3)$ \\
\hline Total & 30 \\
\hline
\end{tabular}

Good compliance - does not miss drug doses

Average - miss one dose a week

Poor - miss more than one dose a week

Out of the 30 diabetics who were on treatment 16 (53.3\%) of them were having good compliance and we're not missing any of their doses and 10 (33.3\%) of them were missing 1 dose a week and $4(14.3 \%)$ of them were missing more than 1 dose per week. (Table 4).

Table-5: Distribution according to a family history of diabetes.

\begin{tabular}{|l|l|l|}
\hline \multicolumn{1}{|c|}{ History } & \multicolumn{1}{c|}{ Cases (\%) } & \multicolumn{1}{c|}{ Controls (\%) } \\
\hline Present & $11(36.6)$ & $15(50.0)$ \\
\hline Absent & $19(73.4)$ & $15(50.0)$ \\
\hline Total & 30 & 30 \\
\hline
\end{tabular}

Among the 30 cases, 11 (36.6\%) of them had a family history of diabetes in their parents or siblings and among the 30 controls, 15 (50\%) of them had a family history of diabetes. (Table 5 ).

Table-6: Type of diet.

\begin{tabular}{|l|l|l|}
\hline \multicolumn{1}{|c|}{ Type of Diet } & \multicolumn{1}{c|}{ Cases (\%) } & \multicolumn{1}{c|}{ Controls (\%) } \\
\hline Vegetarian & $3(10.0)$ & $4(13.3)$ \\
\hline Mixed & $27(90.0)$ & $26(86.7)$ \\
\hline Total & 30 & 30 \\
\hline
\end{tabular}

The majority of cases and controls were eating mixed diet at $27(90 \%)$ and $26 \quad(86.7 \%)$ respectively and only $3(10 \%)$ and 4 (13.3\%) respectively were vegetarians (Table 6). 
Table-7: Body mass index of the study population.

\begin{tabular}{|l|l|l|}
\hline \multicolumn{1}{|c|}{ BMI } & \multicolumn{1}{c|}{ Cases (\%) } & \multicolumn{1}{c|}{ Controls (\%) } \\
\hline$<20.9$ & $0(0.0)$ & $2(6.6)$ \\
\hline $21-25.9$ & $28(93.4)$ & $26(86.6)$ \\
\hline $26-29.9$ & $2(6.6)$ & $2(6.6)$ \\
\hline$>30$ & $0(0.0)$ & $0(0.0)$ \\
\hline Total & 30 & 30 \\
\hline
\end{tabular}

The BMI of the case group was predominantly in the 21 to 25.9 ranges and in the control group also was in the same range ( 93.4 and $86.6 \%$ respectively). 2 subjects $(6.6 \%)$ each in case group and control group were overweight, there were no obese subjects in both the groups and there were 2 $(6.6 \%)$ underweight subjects in the control group (Table 7).

Table-8: Fasting blood glucose of cases.

\begin{tabular}{|l|l|}
\hline \multicolumn{1}{|c|}{ FBS $(\mathrm{mg} / \mathrm{dl})$} & \multicolumn{1}{c|}{ Cases (\%) } \\
\hline $\mathbf{8 0}-\mathbf{1 1 0}$ & \multicolumn{1}{|c|}{$\mathbf{0 . 0 )}$} \\
\hline $111-125$ & $1(3.3)$ \\
\hline $126-140$ & $18(60.0)$ \\
\hline $141-160$ & $5(16.6)$ \\
\hline $161-180$ & $2(6.6)$ \\
\hline $181-200$ & $3(10.0)$ \\
\hline$>200$ & $1(3.3)$ \\
\hline Total & 30 \\
\hline
\end{tabular}

The fasting blood glucose in most of the patients (60\%) was between 126 to $140 \mathrm{mg} / \mathrm{dl}$. There were no patients with an FBS of $<110$ and only one patient with FBS > 200 (Table 8).

Table-9: Postprandial blood glucose levels of cases.

\begin{tabular}{|l|l|}
\hline \multicolumn{1}{|c|}{ PPBG $(\mathrm{mg} / \mathrm{dl})$} & \multicolumn{1}{c|}{ Cases (\%) } \\
\hline $140-159$ & $1(3.3)$ \\
\hline $160-179$ & $18(60)$ \\
\hline $180-199$ & $5(16.6)$ \\
\hline $200-219$ & $2(6.6)$ \\
\hline $220-240$ & $3(10)$ \\
\hline$>240$ & $1(3.3)$ \\
\hline Total & 30 \\
\hline
\end{tabular}

The postprandial blood glucose of most of the patients (60\%) was between 161 - $179 \mathrm{mg} / \mathrm{dl}$. There were $5(16.6 \%)$ patients with PPBS between 180 - $199 \mathrm{mg} / \mathrm{dl}$ and just one patient (3.3\%) each with PPBS < $160 \mathrm{mg} / \mathrm{dl}$ and $>240 \mathrm{mg} / \mathrm{dl}$ (Table 9).

Table-10: HbA1c levels of cases.

\begin{tabular}{|l|l|}
\hline \multicolumn{1}{|c|}{ HBA1c \% } & Cases (\%) \\
\hline$<5.7 \%$ & 0 \\
\hline
\end{tabular}

\begin{tabular}{|l|l|}
\hline $5.8-7 \%$ & $8(26.6)$ \\
\hline $7-9 \%$ & $21(70)$ \\
\hline$>9 \%$ & $1(3.4)$ \\
\hline
\end{tabular}

Among the patients, only $8(26.6 \%)$ had excellent control of diabetes. (Table 10).

Table-11: Vitamin D status.

\begin{tabular}{|l|l|l|l|}
\hline \multicolumn{1}{|c|}{ Vitamin D } & Cases (\%) & Controls (\%) & Total $(\%)$ \\
\hline Deficient $(<20 \mathrm{ng} / \mathrm{ml})$ & $15(50.0)$ & $0(0.0)$ & $15(25.0)$ \\
\hline Insufficient $(21-30 \mathrm{ng} / \mathrm{ml})$ & $13(43.3)$ & 3 & $23(38.3)$ \\
\hline Normal $(31-70 \mathrm{ng} / \mathrm{ml})$ & $2(6.7)$ & $20(66.7)$ & $22(36.7)$ \\
\hline Total & 30 & 30 & 60 \\
\hline
\end{tabular}

Vitamin D deficiency was seen in 15 (50\%) of the cases and none of the controls. Vitamin D insufficiency was seen in $13(43.3 \%)$ of the cases and $10(33.3 \%)$ of controls and normal levels was seen in $2(6.7 \%)$ of cases and $20(66.7 \%)$ of controls. Vitamin D deficiency and insufficiency were seen in most of the diabetic cases. Among the controls none of the subjects showed deficiency, most of the subjects had normal levels of Vitamin D (Table 11).

Table-12: Vitamin D results.

\begin{tabular}{|l|l|l|l|}
\hline \multicolumn{1}{|c|}{ Vitamin D } & \multicolumn{1}{c|}{ CASE } & \multicolumn{1}{c|}{ CONTROL } & P-VALUE \\
\hline Mean \pm SD & $19.91 \pm 7.0$ & $32.22 \pm 4.0$ & $<0.001$ \\
\hline Median (IQR) & $20(15.3,23.8)$ & $31.6(29.1,35.6)$ & $<0.001$ \\
\hline
\end{tabular}

IQR - Inter Quartile Range

The mean vitamin $D$ in cases was $19.91 \mathrm{ng} / \mathrm{ml}$ and the median vitamin $D$ in cases was $20 \mathrm{ng} / \mathrm{ml}$. The mean Vitamin D in controls was $32.22 \mathrm{ng} / \mathrm{ml}$ and the median vitamin $D$ in controls was $31.6 \mathrm{ng} / \mathrm{ml}$. The highest vitamin D level in cases was $37.56 \mathrm{ng} / \mathrm{ml}$ and the lowest vitamin D level in cases was 3.94 $\mathrm{ng} / \mathrm{ml}$. The highest vitamin $\mathrm{D}$ level amongst the controls was $39.41 \mathrm{ng} / \mathrm{ml}$ and the lowest level in controls was $24.54 \mathrm{ng} / \mathrm{ml}$.

Table-13: Correlation between Vitamin D and parameters.

\begin{tabular}{|l|l|l|}
\hline \multicolumn{1}{|c|}{ Characteristic } & \multicolumn{1}{c|}{ Correlation Co-Efficient ( $)$} & P-Value \\
\hline Age & -0.42 & $0.023^{*}$ \\
\hline BMI & -0.18 & 0.347 \\
\hline FBS & -0.37 & $0.045^{*}$ \\
\hline PPBS & -0.41 & $0.026^{*}$ \\
\hline Duration of diabetes & -0.39 & $0.032^{*}$ \\
\hline Diet & -0.09 & 0.243 \\
\hline Hba1C & -0.32 & $0.037 *$ \\
\hline Compliance to therapy & -0.16 & 0.126 \\
\hline Family history & -0.19 & 0.238 \\
\hline
\end{tabular}

*Indicates statistically significant correlation 
There was a significant inverse correlation between vitamin D and type 2 diabetes mellitus ( $p<0.001$ ) (Table 12).

The association between a variable and vitamin D was calculated using the Linear Regression and Correlation method. Age showed an inverse correlation with Vitamin $D(p=0.023)$, with increasing age there was a tendency towards lower levels of vitamin D in both the case and control groups. Fasting blood glucose increased with lower levels of vitamin $D(p=0.045)$. Postprandial blood glucose also increased with lower levels of vitamin $D$ $(p=0.026)$. Vitamin $D$ levels tended to be lower in diabetic cases with a longer duration of diabetes ( $p$ $=0.032)$. HbA1c correlated significantly and inversely with Vitamin D levels ( $p=0.037$ ).
In the present study, BMI did not show any significant correlation with diabetes and vitamin $D$ ( $p=0.347)$. Other characteristics and parameters like diet, compliance to therapy, family history of diabetes, also did not have any significant correlation with the levels of vitamin D (Table 13). All the patients had a normal physical examination. The renal and liver function tests of all the participants were within normal limits.

\section{Discussion}

These results are comparable to the studies done by Christiansen et al. 1982 [6], Stepan et al. [7] 1982, Nyomba et al. 1986 [8], Boucher et al. 1995 [9], Aksoy et al 2000 [10], Isaia et al. 2001 [11], and more recently Cigolini, 2006 [4] and Hypponen and Power in 2006 [5].

Table-14: Case-control studies reporting an inverse association between vitamin d status, and type 2 diabetes mellitus.

\begin{tabular}{|c|c|c|c|c|c|}
\hline 1st author, year & Sex & $\begin{array}{l}\text { Age (mean/ } \\
\text { range) }\end{array}$ & Case group & Control group & Main study results \\
\hline Christiansen, 1982 & M & 36 & $\begin{array}{l}\text { Insulin-treated type } 2 \mathrm{DM}, \mathrm{n} \\
=26\end{array}$ & Age-, sex-matched, $n=14$ & $\begin{array}{l}25-O H D \text { in type } 2 \text { DM vs. controls (17 vs. } 22 \\
\mathrm{ng} / \mathrm{ml} \text { ) }\end{array}$ \\
\hline Stepan, 1982 & $M / F$ & 40-70 years. & $\begin{array}{l}\text { Sulfonylurea treated type } 2 \\
\text { DM, } n=22\end{array}$ & Blood donors, $n=30$ & $\begin{array}{l}25-\mathrm{OHD} \text { in type } 2 \text { DM vs. controls ( } 9 \text { vs. } 14 \mathrm{ng} / \\
\mathrm{ml} \text { ) }\end{array}$ \\
\hline Nyomba, 1986 & $M / F$ & 34-60 years. & $\begin{array}{l}\text { Insulin-treated type } 2 \text { DM, } \\
n=20\end{array}$ & Age and sex-matched, $n=36$ & $\begin{array}{l}25-\mathrm{OHD} \text { in type } 2 \text { DM vs. controls (26 vs. } 35 \\
\mathrm{ng} / \mathrm{ml} \text { ) }\end{array}$ \\
\hline Boucher, 1995 & $M / F$ & 40-57 years. & IGT/type 2 DM, $n=44$ & Age, sex, matched, $\mathrm{n}=15$ & $\begin{array}{l}25-\mathrm{OHD} \text { in IGT/type } 2 \text { DM vs. controls (28 vs. } \\
30 \mathrm{ng} / \mathrm{ml} \text { ) }\end{array}$ \\
\hline Aksoy, 2000 & $M / F$ & 57 years. & $\begin{array}{l}\text { Type } 2 \text { DM with retinopathy, } \\
n=66\end{array}$ & Season-matched, $n=20$ & $\begin{array}{l}25-\mathrm{OHD} \text { in type } 2 \text { DM vs. controls (12 vs. } 24 \\
\mathrm{ng} / \mathrm{ml} \text { ) }\end{array}$ \\
\hline Isaia, 2001 & $F$ & NR & Type 2 DM, n=66 & $n=66$ & $\begin{array}{l}25-\mathrm{OHD} \text { in type } 2 \text { DM vs. controls (9 vs. } 11 \mathrm{ng} / \\
\mathrm{ml} \text { ) }\end{array}$ \\
\hline Cigolini, 2006 & $M / F$ & 61 years. & Type 2 DM, $n=459$ & Age-, sex-matched, $n=459$ & $\begin{array}{l}25-O H D \text { in type } 2 \text { DM vs. controls ( } 20 \text { vs. } 24 \\
\mathrm{ng} / \mathrm{ml} \text { ) }\end{array}$ \\
\hline $\begin{array}{l}\text { Hypponen and Power, } \\
2006\end{array}$ & $M / F$ & 45 & Type 2 DM, $n=125$ & $\begin{array}{l}\text { Sex and season- matched, } \\
n=7,073\end{array}$ & $\begin{array}{l}25-O H D \text { in type } 2 \text { DM vs. controls (15 vs. } 21 \\
\mathrm{ng} / \mathrm{ml} \text { ) }\end{array}$ \\
\hline *Present study, 2020 & $M / F$ & 31-64 years. & Type 2 DM, $n=30$ & Age and sex matched, $\mathrm{n}=30$ & $\begin{array}{l}25-\mathrm{OHD} \text { in type } 2 \text { DM vs. controls (19.91 vs. } \\
32.22 \mathrm{ng} / \mathrm{ml} \text { ) }\end{array}$ \\
\hline
\end{tabular}

However, the mean vitamin D levels were substantially lower among both the cases and controls in studies done by Stepan et al. 1982 [7] (9 vs $14 \mathrm{ng} / \mathrm{ml}$ ) and Isaia et al. 2001 [11] (9 vs 11 $\mathrm{ng} / \mathrm{ml})$, when compared to the present study (19.91 vs $32.22 \mathrm{ng} / \mathrm{ml}$ ). This difference may be attributed to the older age of the subjects in the Stepan group, as increasing age has been associated with decreased vitamin D levels which was confirmed with the present study ( $p-0.023)$.
On the other hand, the participants in the study conducted by Isaia in 2001 [11] were all females, and female sex has been inversely associated with vitamin $D$ levels $[12,13]$ which have also been suggested in the present study (Mean vitamin D levels in female cases 16.28 vs $21.24 \mathrm{ng} / \mathrm{ml}$ in males, and in female controls 46.3 vs $49.12 \mathrm{ng} / \mathrm{ml}$ in males). Albeit studies by Heath et al. 1979 [14] and Ishida et al., 1985 [15] failed to show this inverse correlation between type 2 diabetes and 
Vitamin D. This variation in results may be ascribed to the larger number of young patients in these studies, whereas in the present study, the age of the study and control populations were in between 31 - 64 years (mean age 49 years.) and 32 - 60 years (mean age 46 years.) respectively, which is considerably higher.

Age showed an inverse correlation with Vitamin D levels ( $p-0.023)$, with increasing age there was a tendency towards lower levels of vitamin $D$ in both the case and control groups among both males and females. These findings are in line with studies conducted by T. Hagenau et al. 2009 [16].

Fasting and postprandial blood glucose also increased with lower levels of vitamin $D$ with $p$ values of 0.045 and 0.026 respectively, thereby suggesting that glycaemic control has an inverse correlation with vitamin D levels. These findings are in line with the results from a study done by A.A.Tahrani et al. [17]. This study also suggested an inverse relationship between $\mathrm{HbA} 1 \mathrm{c}$ levels and vitamin $\mathrm{D}$, with $\mathrm{HbA1c}$ higher in the subjects with vitamin $D$ deficiency $(<20 \mathrm{ng} / \mathrm{ml})(8.11 \pm 1.11 \%$ vs $7.33 \pm 1.32 \%, p=0.046)$.
In linear regression analysis, vitamin D deficiency was independently related to $\mathrm{HbA} 1 \mathrm{c}$ in patients with type 2 diabetes mellitus.

BMI did not show any significant correlation with diabetes and vitamin $D$ in the present study ( $p$ 0.347). Contrary to our results, a study by Laqunova et al. 2009 [18], showed an inverse correlation between BMI and vitamin D levels. For both sexes and both age groups, ( $<50$ and $>/=50$ years.) there was a significant decrease in vitamin $D$ levels with increasing BMI. The prevalence of vitamin $D$ deficiency was highest in individuals with a BMI of $>$ or $=40$, being as high as $32 \%$ among women and $46 \%$ among men.

Other characteristics and parameters like diet, compliance to therapy, and family history of diabetes did not have any significant correlation with the levels of vitamin D (Table 13). However, studies by other authors against which to compare our results could not be found.

Some studies have reported an inverse association between vitamin $D$ and the risk of development of Type 2 Diabetes Mellitus. These include the studies done by Scragg et al. 2004 [19] and Snijder et al. 2006 [20]

Table-15: Cross-sectional studies reporting an association between vitamin d status, and the development of type 2 diabetes.

\begin{tabular}{|c|c|c|c|c|c|c|}
\hline 1st author, year & $\operatorname{sex}$ & $\mid$ Age (years) & Cohort & Outcome & Predictor & Main study results \\
\hline \multirow[t]{2}{*}{ Scragg, 2004} & $\mathrm{M} / \mathrm{F}$ & $>20$ & NHANES ( $n=2,766$ non-Hispanic whites) & T2DM & $25-\mathrm{OHD},<18$ to $>32 \mathrm{ng} / \mathrm{ml}$ & OR $1.00,0.25(0.11-0.60)$ \\
\hline & $\mathrm{M} / \mathrm{F}$ & $>20$ & NHANES $(n=8,241)$ & T2DM & $25-\mathrm{OHD},<19$ to $>38 \mathrm{ng} / \mathrm{ml}$ & OR $1.00,0.17(0.08-0.37)$ \\
\hline Snijder, 2006 & $\mathrm{M} / \mathrm{F}$ & 75 (mean) & $n=1235$ & T2DM & $25-\mathrm{OHD},<10$ to $>30 \mathrm{ng} / \mathrm{ml}$ & OR $1.0,1.23(0.50-3.02)$ \\
\hline
\end{tabular}

However, a study on vitamin D levels and prevalence of diabetes as well as the effect of vitamin D supplementation on glycaemic control are beyond the scope of the present study.

\section{Advantages of the study}

This study suggests that hypovitaminosis D is more prevalent among diabetic as compared to the nondiabetic population.

Further, the level of vitamin D showed an inverse correlation with glycaemic control. Larger studies may establish vitamin $D$ deficiency as an independent risk factor for the development and high prevalence of Type 2 Diabetes Mellitus.

\section{Limitations of the study}

01. Small sample size.

02. Did not study the effects of Vitamin D supplementation in achieving better glycaemic control in diabetic patients.

\section{Conclusion}

This study suggests that hypovitaminosis $D$ is more prevalent among diabetic as compared to the nondiabetic population. Further, the level of vitamin D showed an inverse correlation with glycaemic control. Larger studies may establish vitamin D deficiency as an independent risk factor for the development and high prevalence of Type 2 Diabetes Mellitus. 


\section{What does the study add to the existing knowledge?}

The present work threw light on the role of Vitamin $D$ in type 2 diabetes, with levels of vitamin $D$ being significantly lower in the study population. Furthermore, vitamin D levels had shown an inverse correlation with the severity of diabetes.

A review of literature though meager, suggests the salutatory effects of vitamin $D$ supplementation in reducing the risk of type 2 diabetes mellitus. Demonstrating the ability of vitamin $D$ supplementation in preventing diabetes mellitus among at-risk individuals, as well as achieving better glycaemic control and preventing or limiting complications associated with this disease, would be of tremendous therapeutic importance.

Thus more studies involving a larger population of diabetic patients shall be rewarding.

\section{Author's contribution}

Dr. J.V. Srujan: Concept, study design, data collection, and manuscript preparation

Dr. Salla Surya Prakasa Rao: Statistical analysis

\section{Reference}

01. King $H$, Aubert RE, Herman WH. Global burden of diabetes, 1995-2025- prevalence, numerical estimates, and projections. Diabetes Care. 1998;21(9)1414-1431.

doi: $10.2337 /$ diacare.21.9.1414 [Crossref]

02. Marwaha RK, Tandon N, Reddy DR, Aggarwal R, Singh R, Sawhney RC. Prevalence and significance of low 25-hydroxyvitamin $D$ concentrations in healthy subjects in Delhi. Am J Clin Nutr. 2005;82(2)472-475.

doi: $10.1093 /$ ajcn/72.2.472 [Crossref]

03. Shatrugna V, Balakrishna N, Krishnaswamy K. Effect of micronutrient supplement on health and nutritional status of schoolchildren- bone health and body composition. Nutrition. 2006;22(1)S33-S39.

doi: 10.1016/j.nut.2005.07.010 [Crossref]
04. Cigolini $M$, Iagulli MP, Miconi V, Galiotto $M$, Lombardi S, Targher G. Serum 25hydroxyvitamin D3 concentrations and prevalence of cardiovascular disease among type 2 diabetic patients. Diabetes Care. $2006 ; 29(3) 722-724$.

doi: $10.2337 /$ diacare.29.03.06.dc05-2148 [Crossref]

05. Hyppönen E, Power C. Vitamin D status and glucose homeostasis in the 1958 British birth cohort- the role of obesity. Diabetes Care. $2006 ; 29(10) 2244-2246$.

doi: $10.2337 /$ dc06-0946 [Crossref]

06. Christiansen C, Christensen MS, McNair $P$, Nielsen B, Madsbad S. Vitamin D metabolites in diabetic patients- decreased serum concentration of 24, 25-dihydroxy vitamin D. Scand J Clin Lab Invest. 1982;42(6)487-491. [Crossref]

07. Štěpán J, Wilczek H, Justova $V$, Havranek T, Škrha F, Wildtova Z, Formankova J, Pacovský V. Plasma 25-hydroxycholecalciferol in oral sulfonylurea treated diabetes mellitus. Hormone Metabol Res. 1982;14(02)98-100.

doi: $10.1055 / \mathrm{s}-2007-1018934$ [Crossref]

08. Nyomba $B L$, Bouillon $R$, Bidingija $M$, Kandjingu $\mathrm{K}$, De Moor P. Vitamin D metabolites and their binding protein in adult diabetic patients. Diabetes. 1986;35(8)911-915.

doi: $10.2337 /$ diab.35.8.911 [Crossref]

09. Boucher BJ, Mannan N, Noonan K, Hales CN, Evans SJ. Glucose intolerance and impairment of insulin secretion in relation to vitamin $D$ deficiency in east London Asians. Diabetologia. 1995;38(10)1239-1245.

doi: $10.1007 /$ BF00422375 [Crossref]

10. Aksoy H, Akçay F, Kurtul N, Baykal O, Avci B. Serum 1, 25 dihydroxy vitamin D $(1,25(\mathrm{OH})$ 2D3), 25 hydroxy vitamin D (25 (OH) D) and parathormone levels in diabetic retinopathy. Clin Biochem. 2000;33(1)47-51.

doi: $10.1016 / s 0009-9120(99) 00085-5$ [Crossref]

11. Isaia G, Giorgino R, Adami S. High prevalence of hypovitaminosis $D$ in female type 2 diabetic populations. Diabetes Care. $2001 ; 24(8) 1496$.

doi: $10.2337 /$ diacare.24.8.1496 [Crossref] 
12. Holick MF, Siris ES, Binkley N, Beard MK, Khan A, Katzer JT, et al. Prevalence of vitamin D inadequacy among postmenopausal North American women receiving osteoporosis therapy. J Clin Endocrinol Metabol. 2005;90(6)3215-3224.

doi: $10.1210 /$ jc.2004-2364 [Crossref]

13. Sullivan SS, Rosen CJ, Halteman WA, Chen TC, Holick MF. Adolescent girls in Maine at risk for vitamin D insufficiency. J Am Diet Assoc. 2005;105(6)971-974.

doi: 10.1016/j.jada.2005.03.002 [Crossref]

14. Heath HI, Lambert PW. Service FJ, Arnaud SB. Calcium homeostasis in diabetes mellitus. J Clin Endocrinol Metab.

1979;49(3)462-466. doi: 10.1210/jcem-49-3-462 [Crossref]

15. Calvo-Romero JM, Ramiro-Lozano JM. Vitamin D levels in patients with type 2 diabetes mellitus. J Investigat Med. 2015;63(8)921-923.

doi: $10.1097 /$ JIM.0000000000000234 [Crossref]

16. Hagenau T, Vest R, Gissel TN, Poulsen CS, Erlandsen M, Mosekilde L, Vestergaard P. Global vitamin $D$ levels in relation to age, gender, skin pigmentation and latitude- an ecologic metaregression analysis. Osteoporosis Int. $2009 ; 20(1) 133-140$.

doi: 10.1007/s00198-008-0626-y [Crossref]
17. Tahrani AA, Ball A, Shepherd L, Rahim A, Jones $A F$, Bates $A$. The prevalence of vitamin $D$ abnormalities in South Asians with type 2 diabetes mellitus in the UK. Int J Clin Pract. 2010;64(3)351-355.

doi: $10.1111 /$ j.1742-1241.2009.02221.x [Crossref]

18. Laqunova $Z$, Porojnicu AC, Lindberg F, Hexeberg $S$, Moan J. The dependency of vitamin D status on Body Mass Index, gender, age and season. Anticancer Res. 2009;29(9)3713-3720.

[Crossref]

19. Scragg $R$, Sowers $M$, Bell C. Serum 25hydroxyvitamin $D$, diabetes, and ethnicity in the Third National Health and Nutrition Examination Survey. Diabetes care. 2004;27(12)2813-2818. doi: $10.2337 /$ diacare.27.12.2813 [Crossref]

20. Mathieu C, Gysemans C, Giulietti A, Bouillon R. Vitamin $\mathrm{D}$ and diabetes. Diabetologia. 2005;48(7)1247-1257.

doi: $\quad 10.1007 / \mathrm{s} 00125-005-1802-7 \quad$ [Crossref] 